\title{
Cross-sectoral strategies in global sustainability governance: towards a nexus approach
}

\author{
Ingrid Boas $^{1}$ - Frank Biermann ${ }^{2}$ Norichika Kanie ${ }^{3}$
}

Accepted: 15 December 2015/Published online: 29 April 2016

(C) The Author(s) 2016. This article is published with open access at Springerlink.com

\begin{abstract}
The recent shift from the Millennium Development Goals to the much broader Sustainable Development Goals has given further impetus to the debate on the nexus between the multiple sectors of policy-making that the Goals are to cover. The key message in this debate is that different domains - for instance, water, energy and food-are interconnected and can thus not be effectively resolved unless they are addressed as being fully interrelated and interdependent. Yet while this overall narrative is forcefully supported in the new UN 2030 Agenda for Sustainable Development and the 17 Sustainable Development Goals that are the main part of this agenda, many Goals still remain sectoral in their basic outlook. This now requires, we argue, a new focus in both policy and research on the nexus between different Sustainable Development Goals, especially with a view to reforms in the overall institutional setting that is required to sufficiently support such a nexus approach. This article thus examines the nexus approach in the context of the Sustainable Development Goals and identifies multiple avenues for its institutionalisation in global governance.
\end{abstract}

Keywords Nexus - Sustainable development - Global governance $\cdot$ Policy integration

Ingrid Boas

ingrid.boas@wur.nl

Frank Biermann

f.biermann@uu.nl

Norichika Kanie

kanie@sfc.keio.ac.jp

1 Environmental Policy Group, Wageningen University, Hollandseweg 1, 6706 KN Wageningen, The Netherlands

2 Environmental Governance Group, Copernicus Institute of Sustainable Development, Utrecht University, Heidelberglaan 2, 3584 CS Utrecht, The Netherlands

3 Graduate School of Media and Governance, Keio University, 5322 Endo, Fujisawa-shi, Kanagawa 252-0882, Japan 


$\begin{array}{ll}\text { Abbreviations } \\ \text { ECOSOC } & \text { United Nations Economic and Social Council } \\ \text { HLPF } & \text { High-level Political Forum } \\ \text { SDGs } & \text { Sustainable Development Goals } \\ \text { UN } & \text { United Nations } \\ \text { UNEP } & \text { United Nations Environment Programme } \\ \text { UNDESA } & \text { United Nations Department for Economic and Social Affairs } \\ \text { UNGA } & \text { United Nations General Assembly }\end{array}$

\section{Introduction}

The recent shift from the Millennium Development Goals to the much broader Sustainable Development Goals (SDGs) has given further impetus to the debate about how to best address the nexus between the multiple problems and policies that the Goals are supposed to cover, for instance, between policies on water, energy and food. The concern is that these domains are interconnected and thus cannot be effectively addressed unless seen as interactive and interdependent (Hoff 2011). As forcefully argued by a German government representative in preparation to the 2012 United Nations Conference on Sustainable Development in Rio de Janeiro:

Unless the populace and the politics are made aware of the interdependencies of water, energy, and food, a Green Economy will be difficult to secure, and unsustainable practices are destined to continue. Thus a strong signal must be sent to Rio+20 [the 2012 UN Conference on Sustainable Development] that fragmentation of the sectors can no longer be maintained... (Cited in Martin-Nagle et al. 2011, p. 5).

In theory, the new 2030 Agenda for Sustainable Development that has been agreed upon by the United Nations General Assembly (UNGA) in September 2015 is fully cognisant of this problem and includes strong language that is meant to address nexus problems. In particular, if compared to the earlier Millennium Development Goals, the 17 new Sustainable Development Goals are leaning further towards integrating different policy domains in many ways. The new Goals have a broader outlook that takes into account not only socio-economic issues but also ecological dimensions (UNGA 2015).

And yet, the new Goals do not fully and effectively integrate all the different dimensions of sustainable development. While a number of Sustainable Development Goals refer to other policy domains, this still remains somewhat random. The connections between many Goals are weak, and rarely structural or transparent. For instance, the Goal on hunger reduction and food security makes some connections to other issues such as equality, health, climate change, disasters, ecosystem protection and infrastructure. Yet this does not explicitly refer to the interconnections with water and energy, among many other potential connections. Similarly, the Goal on ensuring the availability and sustainable management of water and sanitation for all makes no explicit connection to food or climate change. Some Sustainable Development Goals even focus on only one dimension, such as economic development or the environment. For example, the Goals on marine resources and ecosystem protection address primarily the environmental dimension and are only marginally connected with broader social and economic questions and other Sustainable Development Goals (UNGA 2015). 
We do not deny that there are benefits in having narrowly focussed, sectoral Sustainable Development Goals. For one, focussed and sectoral goals are easier to monitor. They are also easier to communicate to crucial audiences such as civil society, national parliaments and local governments. However, an unintended consequence of such approaches might be incoherent policy-making and eventually a general failure in achieving the Sustainable Development Goals as interconnected domains. As argued by Howells et al. (2013, p. 622), one consequence could be that 'a strategy or policy implemented in one area undermines a policy goal in another'. It is thus essential, we argue, to ensure that the nexus among sustainable development concerns is fully taken into account in implementing the new Sustainable Development Goals. Given that many Goals are broadly sectoral in their outlook, the focus thus needs to be on novel ways of cross-sectoral institutionalisation in the implementation of the 2030 Agenda for Sustainable Development and its core Sustainable Development Goals.

In this article, we seek to contribute to the institutionalising of a 'nexus approach' in the global institutional setting of the Sustainable Development Goals. We engage with numerous existing proposals for policy integration in sustainability governance (see, e.g. Nilsson et al. 2009; Oberthür 2009; Pinkse and Kolk 2012; Kanie et al. 2012; Biermann et al. 2012; Biermann 2014; Bernstein et al. 2014; UNDESA 2014a; Weitz et al. 2014; Young et al. 2014; Abbott and Bernstein 2015), and we aim to make them specific to account for the nexus in implementing the Sustainable Development Goals, and to further the case for more integrated and cross-sectoral strategies. Our approach is based upon qualitative research, drawn from an extensive survey of the literature and primary documents mainly in the area of global environmental and sustainability governance.

We proceed as follows. First, we introduce and define the nexus approach to sustainable development. We outline its emergence and key characteristics, and discuss how the nexus approach differs from related earlier notions of integrated approaches to sustainable development. Second, we discuss how further institutional reforms can help address sustainable development through a nexus approach. As a final step, we conclude.

\section{The nexus between policy domains}

The argument for considering connections between the economic, social and environmental dimensions of sustainable development dates back more than 20 years, at least to the 1992 United Nations (UN) Conference on Environment and Development in Rio de Janeiro. Despite this long period of discursive development and related policy reforms, most observers agree that overall policy effectiveness, especially at the global level, still suffers from a lack of integrated analysis and policy-making. As Klaus Töpfer, a former executive director of the UN Environment Programme (UNEP), recently concluded, 'The original Rio conference discussed environment and development together in a sort of nexus way; however, after Rio we lost a little of this feeling and the nexus faded away. Now, 20 years later, we must reinvigorate this message of sustainable development through a nexus approach' (cited in Martin-Nagle et al. 2011, p. 5). Hence, at the 2012 UN Conference on Sustainable Development, governments reaffirmed, 'the need to further mainstream sustainable development at all levels, integrating economic, social and environmental aspects and recognizing their interlinkages, so as to achieve sustainable development in all its dimensions' (UN 2012, p. 1). The academic community, along with numerous UN agencies, civil society and the private sector, has also argued for long that an 
integrated and holistic approach to sustainable development is essential to achieving real progress (Griggs et al. 2013; Raworth 2012; UNEP 2015; Young et al. 2014; Zerrenner 2014).

In recent years, this debate has been framed under the novel heading of the nexus. The word nexus stands, in general, for 'a connection or series of connections linking two or more things' (Oxford Dictionary 2015). The concept thus denotes the observation that different issue areas are intrinsically interconnected and must thus be governed as such. The nexus approach originated in reference to connections between climate, food, energy and water. It then reflected growing concerns about resource security that result from the food and energy crisis in 2007 and 2008 (Allouche et al. 2015), which had led researchers to examine links between biofuel policies and food security, among other concerns (see, e.g. Hellegers et al. 2008). The nexus approach was soon picked up in the broader sustainable development community. Between 2011 and 2012, numerous conferences and workshops have been held on nexus problems, many of which aimed at supporting the negotiation of the Sustainable Development Goals. Major conferences in this context include the Bonn 2011 Nexus Conference, the South African Water, Energy Food Forum 'Managing the Mega-Nexus' and several workshops held at the sixth World Water Forum (Bizikova et al. 2013, p. 6).

The nexus between water, food, energy and the climate has received special attention in the literature-mainly with the focus on identifying, demonstrating and modelling connections between all of these domains (see, e.g. Bazilian et al. 2011; Rothausen and Conway 2011; Scott et al. 2011; Hoff 2011; Hermann et al. 2012; Bizikova et al. 2013; Howells et al. 2013; Howells and Rogner 2014). The overall argument is that population growth and economic growth 'put significant pressure on energy, water and food demands with growing trade-offs among these three development goals; and will accelerate ecosystem degradation' (The Water Energy and Food Security Resource Platform 2012). As proponents of the nexus approach highlight, 'Water, energy and food sectors are interconnected in important ways, and actions in one sector may either help or harm the other two. Disconnected approaches and silo thinking are more likely to make matters worse' (The Water Energy and Food Security Resource Platform 2012). For example, adaptation to climate change can be very energy intensive (for instance, in case of irrigation systems that rely on additional pumping) (Hoff 2011, p. 32). In that manner, adaptation measures actually negatively affect the reduction of greenhouse gas emissions. Drawing on such findings, policy-makers are often advised to consider special measures that avoid such trade-offs and instead produce cross-sectoral benefits (see, e.g. Hoff 2011; Scott et al. 2011; Hermann et al. 2012; Weitz et al. 2014).

While the connections between the climate, water, energy and food issues are indeed crucial to examine, the idea of the nexus does not need to be limited to these four areas. On the contrary, it can be extended to all Sustainable Development Goals and thus allow for a fully integrative perspective towards sustainable development. For example, the Global Sustainable Development Report—a UN report that aims at strengthening the sciencepolicy interface in the sustainable development agenda-aims at a nexus approach that would be able 'to capture all the goals' (UNDESA 2014a, p. 88). Less explored but equally crucial are, for instance, nexus relationships among the policy domains of health, poverty, gender and education. In a project for the UK Department for International Development on the 'gender-energy-poverty nexus', Clancy et al. (2002) argued that women are much more affected by energy poverty than men. Women and children are often responsible for collecting wood for energy and have thus less time for other activities, such as education. Moreover, women are at higher risk of lung and eye diseases because they are more 
exposed to the burning of biomass when cooking. Women's empowerment (Sustainable Development Goal 5) and education (Sustainable Development Goal 4) thus have clear links with poverty, health, and sustainable and accessible energy (Sustainable Development Goals 1, 3 and 7). Kitamura et al. (2014) have similarly analysed the nexus between education, health and water (Sustainable Development Goals 3, 4 and 6). Education about water usage is vital for ensuring safe water consumption and protecting human health, for instance, by spreading knowledge about how to use well water, prepare water for consumption or handle waste water (Kitamura et al. 2014). In a similar vein, there is a clear link between education, health and food (Iguchi et al. 2014). Through community-based nutritional education programmes, for instance, women can learn about inexpensive nutritious foods for cooking. This in turn positively influences their family's health (Iguchi et al. 2014; Wallace et al. 2014). This shows how a nexus perspective moves beyond its original limited focus on the nexus between climate, water, food and energy, and it explains why it gains traction in the wider field of sustainable development.

However, the nexus approach is not alone in advocating such a message. Similar arguments have been put forward by means of different concepts and ideas, for instance, the notion of an 'integrated earth system' (Schellnhuber and Wenzel 1998) and related to that the concept of integrated 'earth system' governance (Biermann 2007, 2014); the 'principle of environmental policy integration' (Lafferty and Hovden 2003; Nilsson et al. 2009; Biermann et al. 2009; Jordan and Lenschow 2010); and more recently the concept of 'planetary boundaries' (Rockström et al. 2009; Steffen et al. 2015). This leads to the questions of how the nexus approach differs, and why it is able to gain much traction in a widely populated field of concepts and approaches promoting holistic sustainable development. Before answering these questions, we now first outline the basic ideas behind these related concepts.

First, the notion of an integrated earth system allowed situating socio-economic activities within the overall earth system (see, e.g. Griggs et al. 2013; Young et al. 2014). This understanding of an integrated earth system has been further advanced since the 1990s and can be seen as a background also for the integration of the 17 Sustainable Development Goals. As argued by Young et al. (2014, p. 2), we need to 'frame the goals in ways that recognize the systemic challenges associated with the causes and effects of human domination of the Earth System. The systemic challenges have both human and planetary dimensions, and they interact with one another'. The core argument is that human development cannot be stable and prosperous if seen as independent from its integration in the overall earth system. For instance, when governments only seek to enhance economic growth in order to reduce poverty levels, drastic climate change cannot be avoided. In this view, the Sustainable Development Goals need to embrace the interconnectivity of our planetary system to ensure economic, social and environmental stability all at the same time (Young et al. 2014). As forcefully formulated by Griggs et al. (2013, p. 305), 'Earth's life-support system and poverty reduction must be twin priorities for SDGs... because humans are transforming the planet in ways that could undermine development gains'.

This rationale is also embedded in the related concept of planetary boundaries that was originally advanced by Rockström et al. (2009; see also Steffen et al. 2015). The notion of planetary boundaries describes a set of critical thresholds in the earth system, namely climate change; biodiversity loss; the nitrogen cycle; the phosphorus cycle; stratospheric ozone depletion; ocean acidification; global freshwater use; land use change; atmospheric aerosol loading; and chemical pollution (Rockström et al. 2009). Following this concept, human activities should not breach any of these planetary boundaries in order to keep the planet within a 'safe operating space for humanity' (Rockström et al. 2009, p. 472). 
Otherwise, if boundaries were crossed the earth system might experience abrupt and/or irreversible environmental changes with potentially devastating impacts on humanity. The notion of an 'integrated earth system' with numerous 'planetary boundaries' has particularly been used to raise awareness of the environmental dimension of sustainable development. Seen from this perspective, the notion of 'planetary boundaries' functions as a critique of the long-standing dominance of economic and social concerns (in particular economic ones) in politics and policy-making, and also in the field of sustainable development.

The concept of planetary boundaries is, however, still controversial. Due to resistance of numerous governments and some scientists, it has not been explicitly mentioned or explicitly incorporated in the 2030 Agenda for Sustainable Development that was agreed in 2015 (although the concept was included in a Zero Order Draft of the 2012 UN Conference on Sustainable Development as a scientific tool to help set environmental targets) (The Science and Development Network 2012). Developing countries opposed the concept as they were afraid that such planetary boundaries might legitimise limits on their development aspirations with the pretext of ensuring a safe operating space for humanity (Saunders 2014).

A third and related concept is environmental policy integration. This concept originated from the 1987 Brundtland report that centred attention towards the need to integrate environmental policy into sustainable development (WCED 1987; Nilsson et al. 2009, p. 338). The concept's main message is that environmental objectives should be integrated 'into all stages of policy-making in non-environmental policy sectors', and that in doing so, the environment should be granted 'principled priority' vis-à-vis these other policy sectors (Lafferty and Hovden 2003, pp. 9-10; see also discussion in Oberthür 2009; Jordan and Lenschow 2010). It is nonetheless acknowledged that 'other policy objectives will, at times, be deemed more important than environmental concerns' (Lafferty and Hovden 2003 , p. 10). The principle of environmental policy integration has informed many policy proposals in the field of sustainable development. Most were oriented to EU and national levels (see discussion in Jordan and Lenschow 2010), but in recent years also to the level of global governance (see, e.g. Biermann et al. 2009; Nilsson et al. 2009; Oberthür 2009). As environmental protection is generally the focus of this debate, it is not surprising that proposals aiming at a reform of global governance often centred on environmental law or environmental organisations (Biermann et al. 2009; Oberthür 2009), such as calls for a world environment organisation to better coordinate and integrate international environmental policy.

The more recent nexus approach is similar to these concepts. This approach focuses on the connections between different problem domains, such as water, energy, food and the climate. As argued by Allouche et al. (2015, p. 614), 'nexus language has ... sought to frame debates around acute pressures on the world's natural resources generated through a combination of factors, including climate change, global demographic trends of burgeoning population size and increased consumption levels'. In that respect, however, the concept is not much more than a 'new development buzz word' (Allouche et al. 2015, p. 616). One could possibly argue that the central idea behind the nexus approach is narrower than the earlier concepts promoting an integrated approach to sustainable development. Namely, in the debate on the water, food and energy nexus, some important players such as the World Economic Forum have identified and framed 'water' as the most central domain that influences all other others (World Economic Forum 2011). This understanding of the nexus strongly overlaps with the message argued for long in integrated water resource management (Allouche et al. 2015; Benson et al. 2015). 
However, if viewed more broadly, the nexus concept can account for novel interconnections between the three dimensions of sustainable development and in particular-and this is the focus of our argument-for the interconnections among the 17 Sustainable Development Goals. As mentioned, the nexus concept has already been extended to areas such as gender, education and health, and in doing so it helps to prevent a centralisation, or dominance, of any development domains over others. Depending on its usage, the nexus approach is hence especially well equipped to convey the message that all 17 Sustainable Development Goals are interlinked and must be addressed holistically.

This holistic potential of the nexus approach-especially with a focus on the 17 Sustainable Development Goals - may explain why it has attracted so much attention and support in the most recent sustainable development debate. It seems to work well as a novel narrative in the implementation of the Sustainable Development Goals that helps ensure the overall integration of the 2030 Agenda for Sustainable Development. Probably for these reasons, the nexus approach has been embraced by a wide range of crucial players, from UN organisations such as the UN Food and Agriculture Organization, the UN Environment Programme and the UN Department for Economic and Social Affairs (UNDESA), to leading scientists such as Jeffrey Sachs (Allouche et al. 2015). The nexus approach thus seems to have a certain consensual power because various types of actors are interested in being involved in discussions and policies on the nexus in sustainable development as it touches upon and brings together their sectoral interests. Moreover, the broad focus in the nexus approach is better able to ease concerns of developing countries that associate the environmental discussion in sustainable development with an elitist agenda of the global North (Rana 2009). By emphasising the interactions between all dimensions of sustainable development and all Sustainable Development Goals, the nexus approach can thus intersect with core agendas from both North and South.

Another key advantage of the nexus approach is its empirical grounding. This is precisely where the nexus debate has been able to offer most thus far. In the context of 'nexus research', much in-depth analysis of the empirical and policy interlinkages between the domains of sustainable development has been conducted (see, e.g. Clancy et al. 2002; Hoff 2011; Iguchi et al. 2014; Kitamura et al. 2014; Wallace et al. 2014). This has even resulted in the development of an advanced modelling framework on the climate, land (including food), energy and water nexus aimed at making specific and localised recommendations for policy-makers (Howells et al. 2013). This framework has been applied to several pilot countries, including Mauritius and Burkina Faso (Bazilian et al. 2011; Howells et al. 2013; UNDESA 2014a). Also the Global Sustainable Development Report aims for this model to eventually capture all Sustainable Development Goals and in that manner will broaden its usage and application in sustainable development (UNDESA 2014a, p. 88).

In sum, the nexus approach seeks to endorse a cross-sectoral approach to sustainable development. The main argument is that policy domains intertwine and should be approached as such. The next section delves into this nexus approach in the 2030 Agenda for Sustainable Development by examining ways to institutionalise cross-sectoral strategies through strengthened global governance mechanisms. These proposals will build on earlier proposals and ideas put forward by scholars arguing for integrated policy-making on sustainable development, but we will adjust these to the most recent policy development and research insights. 


\section{Institutionalisation of the nexus approach in global governance}

While there is an overwhelming amount of research examining specific nexuses through case studies and compilation of aggregated data, the institutionalisation of the nexus among the Sustainable Development Goals still requires substantially more attention. So far, this debate has seen promising first results at the local level, for example in proposals for a bottom-up institutionalisation of the nexus approach in sustainable development. Weitz et al. (2014) argue, for instance, that individual countries should focus on concrete and situated targets on sustainable development, to ensure that action on sustainable development becomes cross-sectoral and fits the local context and circumstances.

However, local-level institutionalisation alone does not account for trade-offs, cobenefits, interlinkages between development and environment problems across local or national jurisdictions. For instance, water is not merely a local or national commodity. It crosses political boundaries and is thus a concern of transnational governance as well (Conca 2007). In turn, transnational problems of water affect other areas of sustainable development, such as the viability of agricultural practices in different locations, health and energy, but also the resilience of water-scarce or flood-prone cities and infrastructures. A nexus perspective should therefore not just focus on local-level implications and solutions, but also on the transnational and global levels so as to avoid cross-border trade-offs and to stimulate cross-border synergies.

Our discussion hence concentrates on this global transnational dimension of the nexus approach in sustainable development. We examine three areas of institutionalisation of the nexus approach in global sustainability governance. First, we analyse institutional arrangements under the High-level Political Forum on Sustainable Development that may help to ensure cross-sectoral linkages among the Sustainable Development Goals. Second, we look at ways to address the nexus among the Sustainable Development Goals in scientific research and assessments, in order to maximise specific information and advice for all actors, from local institutions up to UN agencies and the High-level Political Forum in the UN system, in order to help address remaining challenges and policy priorities. Finally, we look at the potential role of transnational partnerships that may help to better manage the nexus among the Sustainable Development Goals.

\subsection{Endorsing a nexus approach through the High-level Political Forum}

The 2012 UN Conference on Sustainable Development agreed that a new High-level Political Forum on Sustainable Development should be created (UN 2012, pp. 16-17), partially in order to help coordinate the Sustainable Development Goals that were to be negotiated between 2012 and 2015 (see Chasek and Wagner this issue for background). The forum has replaced the UN Commission on Sustainable Development that was created in 1992 with a similar mandate to help integrate sustainable development policies. Yet this commission had low standing in the UN system, was given too little importance by governments and had insignificant power to influence economic or social decision-making (Biermann 2014).

It is crucial, therefore, that the new High-level Political Forum is more successful than its predecessor. The High-level Political Forum has been given the mandate to guide, recommend and review (UN Sustainable Development Knowledge Platform 2015b), but it does not have the mandate to issue binding regulations or to directly steer UN agencies or other international organisations (Abbott and Bernstein 2015). What is central for the 
forum is its implicit mandate to serve as an 'orchestrator' of other institutions and organisations, in which it can rely on soft modes of governance, such as mobilising and facilitating 'voluntary cooperation in a joint governance effort' (Abbott and Bernstein 2015; Abbott et al. 2013 cited in Bernstein 2013, p. 12). Such an orchestrating role of the High-level Political Forum can help to facilitate a nexus approach to sustainable development. It can bring different regional organisations, states and UN organisations together to create synergies between separate terrains of work. For example, the High-level Political Forum can recommend that the UN Educational, Scientific and Cultural Organisation should collaborate more proactively with UN Water, the Food and Agricultural Organisation and the World Health Organisation for better synergies between the Sustainable Development Goals in the domains of water, food and health through better education.

For such recommendations to be of influence, the High-level Political Forum needs to offer proper guidance on how to implement the Sustainable Development Goals through a nexus approach. To a certain extent, offering such guidance could be as simple as promoting the nexus message, so that cross-sectoral policy-making becomes a more normalised way of thinking about sustainable development among UN agencies and state governments. Guidance can, however, become more concrete and influential through active exchange and collaboration between the High-level Political Forum and the UN Global Sustainable Development Reporting mechanism. As discussed below, the UN Global Sustainable Development Report can offer regular thematic assessments on the nexus between selected issues addressed under the Sustainable Development Goals. This selection can rotate per review; for example, one thematic assessment can focus on the nexus between food and health; another on problems of inequality in the nexus between resilient infrastructures and resilient cities; another on the nexus between sustainable cities and sustainable consumption and production also in relation to the Sustainable Development Goals on food, water and energy; and many more nexuses in sustainable development can become a focus of these thematic assessment reports. These reports can offer the Highlevel Political Forum a solid basis for requests and recommendations to states, regional organisation or UN agencies to better collaborate and therefore help implement a nexus approach to sustainable development.

A concern is the eventual position that will be taken by the new High-level Political Forum in an already 'crowded field of existing orchestrators' (Bernstein et al. 2014, p. 2). This depends on the status that governments are willing to give to the body. The High-level Political Forum will operate under the auspices of both the UN General Assembly and the UN Economic and Social Council (ECOSOC), in a system by which every four years twoday meetings of the forum will be convened under the auspices of the General Assembly, and in all other years the forum will meet under the auspices of the Economic and Social Council for eight days. Due to this dependent relationship, the forum's session agendas must be 'in line with' the Council's thematic focus (Abbott and Bernstein 2015, p. 227). This does not have to pose a barrier, however, to adopting a nexus approach when reviewing and guiding action on the implementation of the Sustainable Development Goals. The 2030 Agenda for Sustainable Development states that the High-level Political Forum will hold 'thematic reviews of progress on the Sustainable Development Goals, including cross-cutting issues' (UNGA 2015, para. 85, emphasis added). In support of Halle and Wolfe (2015), we argue that these cross-cutting thematic reviews should also provide the theme for the Economic and Social Council to ensure alignment between the two bodies. If the Economic and Social Council adopts the suggested theme focussed on cross-cutting issues - such as on the nexus between food security, health and equality-it 
will simultaneously help to endorse a nexus approach to sustainable development in the High-level Political Forum.

From a nexus perspective, it will be important that the High-level Political Forum evolves over time into an integrative steering body for all economic, social and environmental aspects of sustainable development, in a way in which all dimensions are equally voiced and evaluated. That ultimate objective will depend on the effective mandate that governments will be willing to grant to this new body. With a strong mandate, the new High-level Political Forum will be able to serve as an authoritative platform for different national ministries, regional organisations and UN agencies to come together in order to improve policy coordination on specific issues and thus to implement a nexus approach to sustainable development.

\subsection{Progress review to manage a nexus approach: the Global Sustainable Development Report}

Another outcome of the 2012 UN Conference on Sustainable Development is the creation of the Global Sustainable Development Report. This report will be released every 4 years by the UN, in order to inform the High-level Political Forum. In addition, every other year, the UN will produce a more focussed and shorter report (UN Sustainable Development Knowledge Platform 2014). The report's key aim is to assess a wide range of scientific reports, UN reports and national and international assessments, and thus provides a yearly up-to-date account of progress achieved (Halle and Wolfe 2015; Kindornay and Twigg 2015). These reports can allow for regular and up-to-date accounts and thematic assessments of nexus problems related to sustainable development, with a particular focus on global-level and transnational synergies and trade-offs. A focus on the nexus between Sustainable Development Goals has already been actively embraced by the UN Department of Economic and Social Affairs that manages the Global Sustainable Development Report, also in light of a full chapter in the 2014 report on the climate, land, energy and water nexus, and a full chapter on the nexus between oceans, seas, marine resources and human well-being in the 2015 report (UN 2015a; UNDESA 2014a). Officially adopting a nexus approach in these thematic assessment reports would provide an institutionalised procedure through which governments and other UN agencies can obtain regular advice to successfully implement a nexus approach in sustainable development. An important question remains how this could be done in a systematic manner with a secretariat of only a few officers in charge of this report. Enhancement of the function and the capacity of the secretariat are indispensable if the nexus approach is to be taken seriously.

An important facet of this review and assessment process concerns the level of democratic legitimacy. Several observers have argued that it would be important that the voice of civil society - including ordinary citizens-is better heard and taken into account (Kindornay and Twigg 2015; Gellers, this issue). This is also essential for better nexus thinking in the implementation phase of the Sustainable Development Goals, as a wide range of knowledge sources, ideas and experiences can benefit learning and understanding in the still relatively new terrains of the nexus. For example, many countries still treat climate change as an environmental issue, thus ignoring its intersections with other problems of sustainable development, such as poverty, health or even security (e.g. Boas 2015, p. 131; Gupta and Vegelin, this issue). Broader participatory engagement and knowledge exchange on the topic of climate change could help to illuminate its wider intersections with sustainable development. In this context, the High-level Political Forum expressed a clear preference to base this report in a multi-stakeholder and multi-level 
approach (ECOSOC 2014; UN Sustainable Development Knowledge Platform 2014). The Global Sustainable Development Report has made several proposals for such future inclusive assessments, to endorse views from 'minority groups of scientists', 'local and traditional knowledge', 'knowledge of practitioners' and possibly even to include 'nonofficial data from a variety of sources such as remote sensing, mobile phones, road traffic, and user-based crowdsourcing' (UNDESA 2014b, pp. 15, 18). Growing attention to transdisciplinarity, that is, co-development of new knowledge between stakeholders and researchers from multiple disciplines, may enhance such research-based action to achieve a nexus approach to sustainable development.

An additional way to approach such a more grounded monitoring process, also to identify and review nexuses between the Sustainable Development Goals, would be to create a virtual citizen network on sustainable development, using Internet tools. Here one can draw on experiences in the World Health Organisation, where information is obtained from a range of actors, for instance, through the organisation's Global Outbreak Alert and Response Network (Fidler and Gostin 2006, p. 90). These tools help the World Health Organisation to respond to situations not reported by state or scientific actors (Fidler and Gostin 2006, p. 90). Through such virtual networks, the views of local communities, city dwellers and local practitioners can be more actively included in the identification and review of nexuses between the Sustainable Development Goals. Some of these ideas are presented in the 2030 Agenda for Sustainable Development in relation to the proposed Technology Facilitation Mechanism. This Mechanism includes a multi-stakeholder forum on science, technology and innovation for the Sustainable Development Goals and an online platform. Similar kinds of settings, or creating a linkage between the Global Sustainable Development Report, will benefit a grounded approach to identifying and reviewing nexuses in sustainable development.

Another avenue through which the UN Global Sustainable Development Report can facilitate cross-sectoral linkages among the Sustainable Development Goals is to help ensure interaction between global-level and local governance. Local and national governments have a leading role in implementing the Goals and in managing nexuses between policy domains. It should be prevented, however, that local actions and commitments produce transnational trade-offs across different domains of sustainable development. For instance, take the case of India's investments in renewable energy via hydropower projects. From a national perspective, these investments seem to benefit Sustainable Development Goal 7 on reliable and sustainable energy. But these projects may negatively affect water levels within India but also in neighbouring countries, such as Bangladesh, and thus negatively impact on Sustainable Development Goal 6 on sustainable management of water and sanitation for all (Vidal 2013). There needs to be a level of harmony between locally tailored Goals and actions and the global Sustainable Development Goals. One way to achieve this is that the Global Sustainable Development Report develops a synthesis of national reports on sustainable development and on that basis highlights transnational synergies and trade-offs between achievements on the Sustainable Development Goals. An even more effective way forward might be to draw on regional review mechanisms (Halle and Wolfe 2015; Kindornay and Twigg 2015). Regional forums, such as the African Peer Review Mechanism or the Asia-Pacific Forum on Sustainable Development, could be asked to identify cross-border or regional problems and synergies that result from implementing the Sustainable Development Goals, and to identify key nexuses in sustainable development that require more regional attention. Their regional report can in turn inform the Global Sustainable Development Report, allowing for a global assessment of the synergies and trade-offs across policy domains. 


\subsection{Transnational 'nexus' partnerships?}

Third, the nexus between different Sustainable Development Goals could be addressed by transnational partnerships on specific connections. Managing a nexus is a new emerging field of expertise, still characterised by much uncertainty and knowledge gaps. Sharing knowledge and practices, and creating new knowledge, is therefore a vital role for transnational partnerships (Pinkse and Kolk 2012).

Nexus partnerships could draw on the institutional design of multi-stakeholder partnerships created during the 2002 World Summit on Sustainable Development (Bäckstrand et al. 2012). Many more of such partnerships have been announced since the 2012 UN Conference on Sustainable Development aiming to implement sustainable development (HLPF n.d.). If a set of such partnerships are designed to ensure nexuses between the Sustainable Development Goals on a cross-boundary level, they would become particularly well tailored to account for transnational interlinkages and trade-offs. There are already cases of partnerships seeking to achieve the Sustainable Development Goals, but again their focus is primarily on one Goal only (such as Champions 12.3), and only a limited number of such initiatives recognise the linkage between Goals (such as the OPEN 2030 project). In many proposed partnerships, a nexus focus can be further strengthened. Take for example the Cap-Net UN Development Programme international network for capacity development in sustainable water management, which is a partnership under the Sustainable Development Goal on water and consists of a large transnational network in the global South focused on capacity building, learning and best practice exchange (UN Sustainable Development Knowledge Platform n.d.). While making important connections to questions of justice, education, access and gender, it does remain primarily focussed on the water sector. There is no mentioning of possible trade-offs or synergies with the related sectors on energy and food, which should, however, be central to sustainable water management. If it would add this focus to its network, there would be a platform to informally discuss these crucial transnational synergies and trade-offs of water projects. This is especially relevant as many of its sub-networks have a regional focus, such as the Latin America Water, Education and Training Network. Such informal platforms can further stimulate the implementation of a transnational nexus approach to sustainable development by learning and knowledge exchange across policy domains without that this has to result in complex and formal political discussions about cross-border nexus problems.

The High-level Political Forum could play an important role in promoting a nexus approach in such transnational partnerships. Facilitated by assessments and thematic reviews by the Global Sustainable Development Report, it could highlight which crosssectoral policy problems are in need of more action and better implementation by transnational partnerships. In cases where UN agencies are actively involved in such partnerships - as is the case for Cap-Net in the UN Development Programme- the Highlevel Political Forum could even adopt a more directive approach by giving specific advice to UN agencies as to how they can make their current activities more cross-sectoral.

\section{Conclusion}

The nexus approach raises further awareness of the message that interconnections between different policy domains need to obtain central attention to avoid trade-offs in sustainable development. While nexus thinking has not become firmly embedded within the system of 
the new Sustainable Development Goals, it is actively supported by elite actors and even by the UN Global Sustainable Development Report.

To further the institutionalisation of the nexus approach within the domain of sustainable development, we have set out and discussed three related proposals for global sustainability governance. First of all, we argue for the new High-level Political Forum to adopt a nexus perspective in its efforts to review and guide the implementation of the Sustainable Development Goals, with assistance from the Global Sustainable Development Report. Related to that, we argue that the effectiveness of the forum in achieving such a strategy would be enhanced if it really serves to function at the highest political level. Second, we argue for the Global Sustainable Development Report to further institutionalise a nexus approach in its assessment reports of the implementation of the Sustainable Development Goals-for instance, through thematic reviews or by synthesising regional reporting on trade-offs and synergies that result from implementing the Sustainable Development Goals. Third and final, we propose the design of partnerships focussed on cross-national nexuses in sustainable development. This provides a good opportunity to foster the implementation of a nexus approach on a transnational level.

To conclude, the nexus approach offers a new impetus to the debate on policy interlinkages and integration in the domain of sustainable development. Clearly, there are still many challenges ahead, ranging from the still limited mandate of the Highlevel Political Forum to the capacity of the Global Sustainable Development Report secretariat and regional organisations to successfully review and actively endorse a nexus approach to sustainable development. On the positive side, first steps have already been taken towards institutionalising a nexus approach-it has, for instance, already featured in two Global Sustainable Development Reports. Nexus thinking and the use of the term as such are also rapidly catching on in a number of academic, government and UN circles. In building on old and existing ideas, it therefore does succeed in creating a new momentum to further integrate and institutionalise a crosssectoral approach to sustainable development.

Open Access This article is distributed under the terms of the Creative Commons Attribution 4.0 International License (http://creativecommons.org/licenses/by/4.0/), which permits unrestricted use, distribution, and reproduction in any medium, provided you give appropriate credit to the original author(s) and the source, provide a link to the Creative Commons license, and indicate if changes were made.

\section{References}

Abbott, K. W., \& Bernstein, S. (2015). The High-level Political Forum on sustainable development: Orchestration by default and design. Global Policy, 6(3), 222-233.

Allouche, J., Middleton, C., \& Gyawali, D. (2015). Technical veil, hidden politics: Interrogating the power linkages behind the nexus. Water Alternatives, 8(1), 610-626.

Bäckstrand, K., Campe, S., Chan, S., Mert, A., \& Schäferhoff, M. (2012). Transnational public-private partnerships. In F. Biermann \& P. Pattberg (Eds.), Global environmental governance reconsidered (pp. 123-148). Cambridge, MA: The MIT Press.

Bazilian, M., Rogner, H., Howells, M., Hermann, S., Arent, D., Gielen, D., et al. (2011). Considering the energy, water and food nexus: Towards an integrated modelling approach. Energy Policy, 39(12), 7896-7906.

Benson, D., Gain, A. K., \& Rouillard, J. J. (2015). Water governance in a comparative perspective: From IWRM to a "nexus" approach? Water Alternatives, 8(1), 756-773. 
Bernstein, S. (2013). The role and place of the High-level Political Forum in strengthening the global institutional framework for sustainable development. https://sustainabledevelopment.un.org/content/ documents/2331Bernstein study on HLPF.pdf. Accessed October 25, 2015.

Bernstein, S., Gupta, J., Andresen, S., Haas, P. M., Kanie, N., Kok, M., et al. (2014). Coherent governance, the UN and the SDGs (No. POST2015/UNU-IAS Policy Brief No. 4). Tokyo: UNU-IAS.

Biermann, F. (2007). "Earth system governance" as a crosscutting theme of global change research. Global Environmental Change, 17(3-4), 326-337.

Biermann, F. (2014). Earth system governance: World politics in the anthropocene. Cambridge, Massachusetts: The MIT Press.

Biermann, F., Davies, O., \& van der Grijp, N. (2009). Environmental policy integration and the architecture of global environmental governance. International Environmental Agreements: Politics, Law and Economics, 9(4), 351-369.

Biermann, F., Abbott, K., Andresen, S., Bäckstrand, K., Bernstein, S., Betsill, M. M., et al. (2012). Navigating the anthropocene: Improving earth system governance. Science, 335, 1306-1307.

Bizikova, L., Roy, D., Swanson, D., Venema, H. D., \& McCandless, M. (2013). The Water-Energy-Food Security Nexus: Towards a practical planning and decision-support framework for landscape investment and risk management. Winnipeg, Canada: IISD.

Boas, I. (2015). Climate migration and security. Securitisation as a strategy in climate change politics. New York: Routledge.

Clancy, J. S., Skutsch, M., \& Batchelor, S. (2002). The Gender-Energy-Poverty Nexus. Finding the energy to address gender concerns in development. London: DFID.

Conca, K. (2007). Transnational dimensions of freshwater ecosystem governance. In A. R. Turton, H. J. Hattingh, G. A. Maree, D. J. Roux, M. Claassen, \& W. F. Strydom (Eds.), Governance as a trialogue: Government-society-science in transition (pp. 101-121). Berlin: Springer.

Economic and Social Coucill (ECOSOC). (2014). Options for the scope and methodology for a global sustainable development report. http://www.un.org/ga/search/view_doc.asp?symbol=E/2014/ 87\&Lang=E. Accessed October 25, 2015.

Fidler, D. P., \& Gostin, L. O. (2006). The new international health regulations: An historic development for international law and public health. The Journal of Law, Medicine \& Ethics, 34(1), 85-94.

Griggs, D., Stafford-Smith, M., Gaffney, O., Rockström, J., Ohman, M. C., Shyamsundar, P., et al. (2013). Sustainable development goals for people and planet. Nature, 495, 305-307.

Halle, M., \& Wolfe, R. (2015). Architecture for review and follow-up of the SDGs: Options for the Highlevel Political Forum. Winnipeg, Canada: IISD.

Hellegers, P., Zilberman, D., Steduto, P., \& McCornick, P. (2008). Interactions between water, energy, food and environment: Evolving perspectives and policy issues. Water Policy, 10(S1), 1-10.

Hermann, S., Welsch, M., Segerstrom, R. E., Howells, M. I., Young, C., Alfstad, T., et al. (2012). Climate, land, energy and water (CLEW) interlinkages in Burkina Faso: An analysis of agricultural intensification and bioenergy production. Natural Resources Forum, 36(4), 245-262.

High-level Political Forum on sustainable development (HLPF). (n.d.). Multi-stakeholder partnerships for sustainable development (HLPF Brief No. 3). https://sustainabledevelopment.un.org/content/ documents/1312HLPF_Brief_3.pdf. Accessed October 25, 2015.

Hoff, H. (2011). Understanding the Nexus. Background paper for the Bonn2011 Nexus Conference. Stockholm: Stockholm Environment Institute.

Howells, M., Hermann, S., Welsch, M., Bazilian, M., Segerström, R., Alfstad, T., et al. (2013). Integrated analysis of climate change, land-use, energy and water strategies. Nature Climate Change, 3(7), 621-626.

Howells, M., \& Rogner, H. (2014). Assessing integrated systems. Nature Climate Change, 4(7), $246-247$.

Iguchi, M., Ehara, T., Yamazaki, E., Tasaki, T., Abe, N., Hasimoto, S., \& Yamamoto, Y. (2014). Ending the double burden of malnutrition: Addressing the food and health nexus in the Sustainable Development Goals (POST2015/UNU-IAS Policy Brief No. 6). Tokyo: UNU-IAS.

Jordan, A., \& Lenschow, A. (2010). Environmental policy integration: A state of the art review. Environmental Policy and Governance, 20(3), 147-158.

Kanie, N., Betsill, M. M., Zondervan, R., Biermann, F., \& Young, O. R. (2012). A charter moment: Restructuring governance for sustainability. Public Administration and Development, 32, 292-304.

Kindornay, S., \& Twigg, S. (2015). Establising a workable follow-up and review process for the Sustainable Development Goals. London: ODI.

Kitamura, Y., Yamazaki, E., Kanie, N., Edwards Jr., B. D., Rai Shivakoty, B., Kumar Mitra, B., et al. (2014). Linking education and water in the Sustainable Development Goals (POST2015/UNI-IAS Policy Brief No. 2). Tokyo: UNU-IAS.

Lafferty, W., \& Hovden, E. (2003). Environmental policy integration: Towards an analytical framework. Environmental Politics, 12(3), 1-22. 
Martin-Nagle, R., Howard, E., Wiltse, A., \& Duncan, D. (2011). Conference synopsis. Bonn2011 conference: The water, energy and food security nexus-Solutions for the green economy. Bonn: German Federal Government.

Nilsson, M., Pallemaerts, M., \& von Homeyer, I. (2009). International regimes and environmental policy integration: Introducing the special issue. International Environmental Agreements: Politics, Law and Economics, 9(4), 337-350.

Oberthür, S. (2009). Interplay management: Enhancing environmental policy integration among international institutions. International Environmental Agreements: Politics, Law and Economics, 9(4), 371-391.

Oxford Dictionaries. (2015). Nexus. http://www.oxforddictionaries.com/definition/english/nexus. Accessed October 25, 2015.

Pinkse, J., \& Kolk, A. (2012). Addressing the climate change-sustainable development nexus: The role of multistakeholder partnerships. Business \& Society, 51(1), 176-210.

Rana, M. M. P. (2009). Sustainable city in the global North and South: Goal or principle? Management of Environmental Quality: An International Journal, 20(5), 506-521.

Raworth, K. (2012). A safe and just space for humanity. Can we live within the doughnut?. Oxford: Oxfam.

Rockström, J., Steffen, W., Noone, K., Persson, Å., Stuart Chapin, F., Lambin, E. F., et al. (2009). A safe operating space for humanity. Nature, 461, 472-475.

Rothausen, S. G. S. A., \& Conway, D. (2011). Greenhouse-gas emissions from energy use in the water sector. Nature Climate Change, 1(4), 210-219.

Saunders, F. P. (2014). Planetary boundaries: at the threshold... again: Sustainable development ideas and politics. Environment, Development and Sustainability, 17(4), 823-835.

Schellnhuber, H.-J., \& Wenzel, V. (1998). Preface. In H. J. Schellnhuber \& V. Wenzel (Eds.), Earth system analysis: Integrating Science for sustainability (pp. vii-xvi). Berlin: Springer.

Scott, C., Pierce, S., Pasqualetti, M. J., Jones, A. L., Montz, B. E., \& Hoover, J. H. (2011). Policy and institutional dimensions of the water-energy nexus. Energy Policy, 39(10), 6622-6630.

Steffen, W., Richardson, K., Rockström, J., Cornell, S. E., Fetzer, I., Bennett, E. M., et al. (2015). Planetary boundaries: Guiding human development on a changing planet. Science, 347(6223), 736-746.

The Science and Development Network. (2012). Rio + 20 zero draft accepts "planetary boundaries". http://www.scidev.net/global/water/news/rio-20-zero-draft-accepts-planetary-boundaries-.html. Accessed October 25, 2015.

The Water Energy \& Food Security Resource Platform. (2012). Messages from the Bonn 2011 conference: The water, energy and food security nexus-solutions for a green economy. http://www.water-energyfood.org/en/news/view_274/messages-from-the-bonn2011-nexus-conference.html. Accessed October $25,2015$.

United Nations (UN). (2012). Report of the united nations conference on sustainable development. Rio de Janeiro: UN.

United Nations (UN). (2014). Sustainable development knowledge platform. Global sustainable development report. https://sustainabledevelopment.un.org/index.php?menu=1621. Accessed October 25, 2015.

United Nations (UN). (2015a). Global sustainable development report (2015th ed.). New York: UN.

United Nations (UN). (2015b) Sustainable development knowledge platform. High-level Political Forum on sustainable development. https://sustainabledevelopment.un.org/hlpf. Accessed June 14, 2015

United Nations (UN). (n.d.). Sustainable development knowledge platform. Partnerships for SDGs. https:// sustainabledevelopment.un.org/partnership/?p=8936. Accessed December 10, 2015.

United Nations Department of Social and Economic Affairs (UNDESA). (2014a). Prototype global sustainable development report. New York: UN.

United Nations Department of Social and Economic Affairs (UNDESA). (2014b). Prototype global sustainable development report. Executive summary. UN: New York.

United Nations Environment Programme (UNEP). (2015). Water-energy-food nexus. http://www.unep.org/ esm/Waterecosystems/Thematicareas/Water-Energy-Foodnexus/tabid/131727/Default.aspx. Accessed October 25, 2015.

United Nations General Assesmbly (UNGA). (2015). Transforming our world: the 2030 agenda for sustainable development, A/RES/70/1. New York: UN.

Vidal, J. (2013). China and India 'water grab' dams put ecology of Himalayas in danger. Guardian, 10 August. http://www.theguardian.com/global-development/2013/aug/10/china-india-water-grab-damshimalayas-danger. Accessed December 10, 2015.

Wallace, L. J., Summerlee, A. J. S., Dewey, C. E., Hak, C., Ann Hall, N. P., \& Charles, C. V. (2014). Women's nutrient intakes and food-related knowledge in rural Kandal province, Cambodia. Asia Pacific Journal of Clinical Nutrition, 23, 263-271. 
Weitz, N., Huber-Lee, A., Davis, M., \& Hoff, H. (2014). Cross-sectoral integration in the Sustainable Development Goals: A nexus approach. Stockholm: Stockholm Environment Institute.

World Commission on Environment and Development (WCED). (1987). Our common future, report by the World Commission on Environment and Development. Oxford: Oxford University Press.

World Economic Forum. (2011). Water security. The water-food-energy-climate nexus. Washington: Island Press. http://www3.weforum.org/docs/WEF_WI_WaterSecurity_WaterFoodEnergyClimateNexus_ 2011.pdf. Accessed October 25, 2015.

Young, O. R., Underdal, A., Kanie, N., Andresen, S., Bernstein, S., Biermann, F., et al. (2014). Earth system challenges and a multi-layered approach for the sustinable development goals (Post2015/UNU-IAS Policy Brief No. 1). Tokyo: UNU-IAS.

Zerrenner, K. (2014, December 19). Is water the new bottom line for the private sector? The water, energy \& food security resource platform. http://www.water-energy-food.org/en/news/view_2241/is-waterthe-new-bottom-line-for-the-private-sector.html. Accessed October 25, 2015. 